\title{
God måltidsrytme er bra for helsen
}

\author{
Matinntak kun på dagtid gir bedre \\ søvn, mindre vektoppgang og bedre \\ hjertehelse - i hvert fall hos banan- \\ fluer.
}

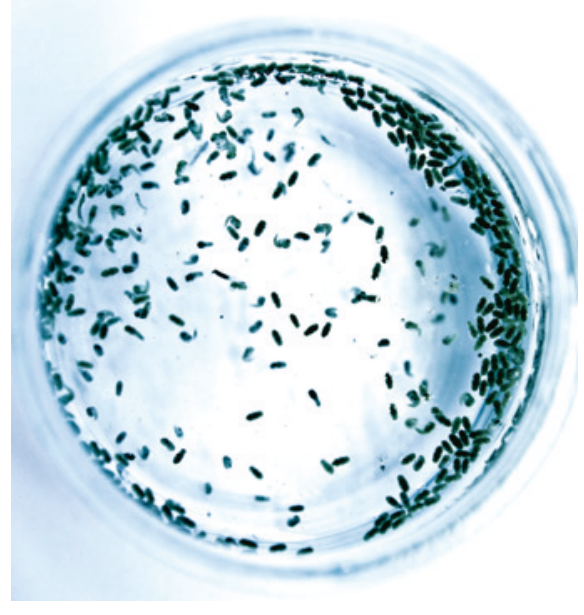

Illustrasjonsfoto: Science Photo Library
Den biologiske klokken hjelper dyr til å koordinere aktiviteten i takt med døgnets syklus av lys og mørke. Hos mennesker kan forstyrrelser i døgnrytmen gi økt risiko for sykdom. Blir helsen også påvirket av måltidsrytmen? Dette er nylig undersøkt hos bananfluen, som er en mye brukt forskningsmodell (1).

Voksne bananfluer ble delt i to grupper den ene fikk kun tilgang på mat på dagtid (12 timer), den andre fikk tilgang på mat hele døgnet. Kaloriinntaket og aktiviteten var omtrent likt i de to gruppene. I gruppen med tidsbegrenset tilgang var det bedre søvn, mindre vektoppgang og redusert aldring av hjertet enn i den andre gruppen. Ut fra genetiske analyser identifiserte man ulike komponenter som medierte disse gunstige effektene, deriblant såkalte klokkegener.

- Disse interessante funnene viser nok en gang at forstyrrelser i det biologiske urverket kan ha ugunstige effekter på helsen, sier seniorforsker Shanbeh Zienolddiny ved Statens arbeidsmiljøinstitutt. - Det sentrale biologiske urverket, som er lokalisert i den suprachiasmatiske nukleus i hjernen, styres av lys-mørke-syklusen. Ved å sende signaler til alle celler i kroppen kontrollerer det sentrale urverket energiinntak, søvn og andre fysiologiske aktiviteter. Det biologiske urverket styres av en rekke gener kjent som klokkegener. Per i dag vet vi om ca. 15 sentrale klokkegener. I tillegg er det gener som kontrollerer produksjon og metabolisme av natthormonet melatonin, som er viktig i synkroniseringen av det biologiske urverket.

Det er for tiden mye oppmerksomhet rettet mot helseeffekter av komponentene i maten vi spiser, mens det er relativt lite kjent hvordan samspillet mellom klokkegener og spisemønstre påvirker helsen, sier Zienolddiny.

\section{Trine B. Haugen}

Tidsskriftet

\section{Litteratur}

1. Gill S, Le HD, Melkani GC et al. Time-restricted feeding attenuates age-related cardiac decline in Drosophila. Science 2015; 347: 1265-9.

\section{Gullregn gir røykeslutt?}

\section{Cytisin, som finnes i gullregn, er en billig og effektiv medisin for røyke- slutt, ifølge en ny studie.}

Det finnes flere legemidler som kan være til hjelp for å slutte å røyke, blant annet vareniklin, nikotinpreparater og bupropion. I en studie fra New Zealand har man undersøkt om cytisin, som ekstraheres fra planten gullregn (Cytisus laburnum), kan brukes til dette formålet (1). Cytisin, som i likhet med vareniklin og nikotin er en acetylkolinagonist, kan ikke patenteres og koster bare en brøkdel av vareniklin.

1310 røykere som var motivert for røykeslutt, ble randomisert til behandling med enten cytisin eller nikotinpreparater. Etter seks måneder hadde 143 personer i cytisingruppen og 100 i nikotingruppen vært røykfrie i minst én måned $(\mathrm{p}=0,002)$. Bivirkninger som kvalme, oppkast og søvnforstyrrelser var vanligere med cytisin enn med nikotin.

- Dette er en interessant studie, sier Frode Gallefoss, som er forskningssjef ved Sørlandet sykehus. - Studien har en pragmatisk inkludering, noe som gir høy overføringsverdi til klinisk praksis. Men det er også klare svakheter: Studien er ikke blindet, oppfølgingstiden er på kun seks måneder, behandlingstiden er ulik gruppene imellom, det er en overvekt av kvinner, og cytisin ble gitt gratis, mens nikotinpreparatene kostet penger. Dessuten var en tredel av deltakerne maorier, noe som kan svekke studiens generaliserbarhet, sier han.

- Det viktigste nå er å finne ut om cytisin er like effektivt og trygt som vareniklin. For å teste dette kreves en randomisert, kontrollert studie hvor 12-måneders abstinensrater sammenliknes, sier Gallefoss.

\section{Inge Rasmus Groote}

Tidsskriftet

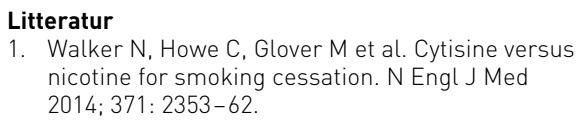

Litteratur

1. Walker N, Howe C, Glover M et al. Cytisine versus nicotine for smoking cessation. N Engl J Med 2014; 371: 2353-62.

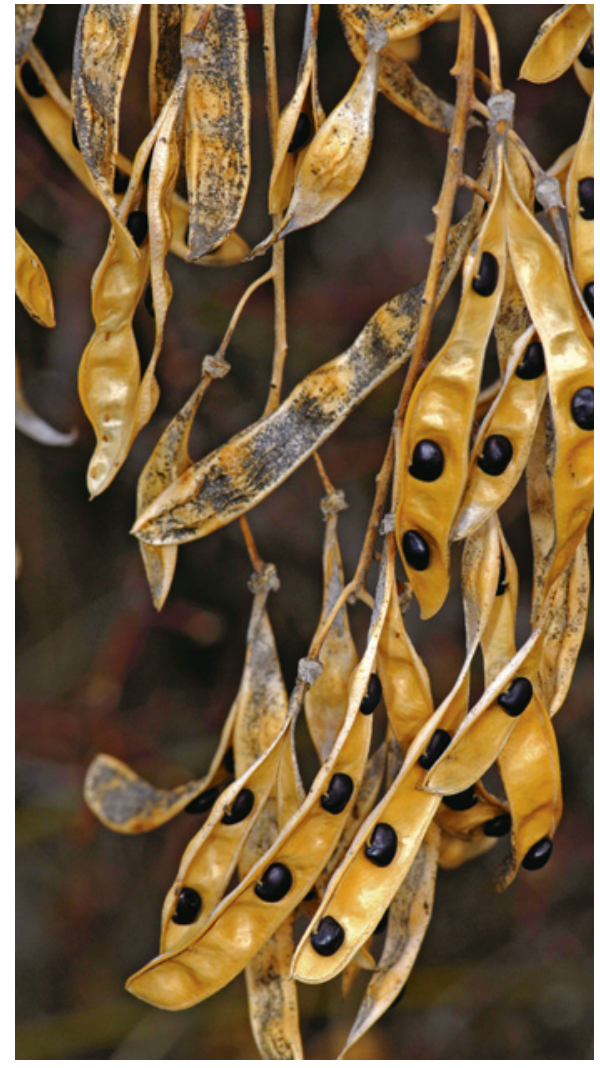

Illustrasjonsfoto: Rafael Campillo/NTB scanpix 